\title{
STUDI KERAGAMAN POLA PITA DNA DAN KESERAGAMAN POPULASI KELAPA GENJAH SALAK (GSK) BERDASARKAN PENANDA RAPD
}

\author{
Novarianto Hengky ${ }^{1}$, Semuel D. Runtunuwu $u^{2,3}$, Edy. F. Lengkong ${ }^{3}$, \\ dan Merlyn Singkoh ${ }^{4}$
}

1). Balai Penelitian Tanaman Kelapa dan Palma Lain (BALITKA) Mapanget, ${ }^{2)}$ Lab. Fisiologi
Tanaman Fakultas Pertanian UNSRAT ${ }^{3)}$ Lab. Genetika dan Pemuliaan Tanaman Fakuktas
Pertanian UNSRAT, ${ }^{4)}$ Mahasiswa Jurusan Budidaya Pertanian, Fakultas Pertanian UNSRAT

ABSTRACT

Novarianto, H., et. al. 2007. The Study of the Variety of DNA Tape Form and the Coconut Genjah Salak Population Variety Based on RAPD Code. Eugenia 13 (1) : 109-118.

The goal of this research to study the variety of DNA tape form and the population variety of coconut Genjah Salak (GSK) based on RAPD code (Randomly Amplified Polymorphic DNA). 25 trees individu of coconut GSK was amplification the genomic of DNA using 35 primer Operon Kit A and Kit B. The coconut GSK individu tree that were analyse was selected based on the female flower production, with average above 40 female flower. The electroforesis of DNA result of amplification PCR get tape form monomorfic and polimorfic between 25 individu coconut GSK trees that was analyzed. OPA 09 primer and OPB 06 get the result of monomorfic tape form, other wise the OPA 13 primer, OPB 05 and OPB 10 get polimorfic tape form. The genetic similarity in coconut Genjah Salak (GSK) population based on RAPD code rate was $88 \%$ or have the variety genetic of $12 \%$. Therefore based of this similarity the coconut GSK population was clustering in five groups. The goal of this research to study the variety of DNA tape form and the population variety of coconut Genjah Salak (GSK) based on RAPD code (Randomly Amplified Polymorphic DNA). 25 trees individu of coconut GSK was amplification the genomic of DNA using 35 primer Operon Kit A and Kit B. The coconut GSK individu tree that were analyse was selected based on the female flower production, with average above 40 female flower. The electroforesis of DNA result of amplification PCR get tape form monomorfic and polimorfic between 25 individu coconut GSK trees that was analyzed OPA 09 primer and OPB 06 get the result of monomorfic tape form, other wise the OPA 13 primer, OPB 05 and OPB 10 get polimorfic tape form. The genetic similarity in coconut Genjah Salak (GSK) population based on RAPD code rate was $88 \%$ or have the variety genetic of $12 \%$. Therefore based of this similarity the coconul GSK population was clustering in five groups.

Keywords : Keragaman genetic, kelapa Genjah Salak (GSK), Randomly Amplified Polymorphic DNA (RAPD)

\section{PENDAHULUAN}

Kelapa Genjah Salak (GSK) ditemukan akhir tahun 1970 oleh Ir. H.T. Luntungan, MSc pemulia kelapa dari Pakuwon. Kelapa ini berasal dari daerah Pematang Panjang, Kalimantan Selatan dan tumbuh di lahan gambut. Kelapa Genjah Salak telah dikonservasi di tiga kebun koleksi plasma nutfah yaitu, Mapanget (Sulawesi Utara), Pakuwon (Jawa Barat) dan Sikijang (Riau) (Tampake 2003). 
Produksi buah umumnya dimulai pada umur 2-3 tahun setelah penanaman, jumlah buah berkisar antara 80-120 per pohon. Karakteristik komponen buah kelapa GSK adalah berat buah utuh 809 $\mathrm{g}$; berat daging buah $322 \mathrm{~g}$ (ratio terhadap buah utuh $39,7 \%$ ); berat sabut 194,3 $\mathrm{g}$ (ratio terhadap buah utuh $24,0 \%$ ); berat air buah $130,8 \mathrm{~g}$ (ratio terhadap buah utuh $16,2 \%$ ) dan berat tempurung 165,1 $\mathrm{g}$ (ratio terhadap buah utuh $20,0 \%$ ). Kelapa GSK mempunyai kandungan material kering yang tinggi sekitar $55 \%$. GSK agak peka terhadap kekeringan (Akuba 1998) dan tahan terhadap penyakit Phytophthora palmivora (Billote 1996 dan Runtunuwu, Sinaga, Hartana 1999)

Kelapa ini telah digunakan sebagai tetua dalam persilangan untuk mendapatkan kelapa hibrida yang memiliki keunggulan yaitu cepat berbuah, jumlah buahnya banyak dan kandungan kopra berkualitas karena kadar galaktomanan rendah (Tampake 2003). Galaktomanan merupakan salah satu penyebab sifat kenyal (rubbery) pada kopra. Sifat kenyal akan menurun sejalan dengan menurunnya kadar galaktomanan (Djatmiko 1991).

Kelapa Genjah Salak (GSK) telah disilangkan dengan empat kultivar kelapa Dalam Unggul yaitu Dalam Igo Duku (DID) asal Maluku, kelapa Dalam Tahity (DTY) asal Kepulauan Pasifik, kelapa Dalam Rennel (DRL) asal Kepulauan Salomon dan kelapa Dalam Tenga (DTA) asal Sulawesi Utara. Hasil pengamatan pada tingkat bibit memperlihatkan vigor pertumbuhan bibit terbaik pada silangan GKS x DID dibandingkan ketiga silangan lainnya. Sampai umur lima tahun keempat hibrida telah mencapai $100 \%$ berbunga, sedangkan kontrolnya KHINA 1 (Genjah Kuning Nias x Dalam Tenga) baru $95 \%$ (Tenda 2004).
Masalah yang dihadapi dalam pemanfaatan koleksi plasma nutfah kelapa GSK adalah tanaman yang dikoleksi berasal dari buah hasil persilangan terbuka (open pollinated). Hal ini akan menyebabkan terdapatnya keragaman diantara individu pohon, yang akan menghasilkan kelapa hibrida yang beragam pula. Padahal kelapa hibrida yang dihasilkan diharapkan memiliki penampilan yang seragam. Aror (2004) yang menganalisis keragaman genetik berdasarkan penanda RAPD menemukan adanya keragaman diantara 30 individu pohon kelapa GSK yang dikoleksi BALITKA dari PT. Pagelaran, Jawa Tengah. Berdasarkan hal tersebut diatas, maka penelitian ini dilakukan untuk mempelajari pola pita DNA dan tingkat keseragaman kelapa GSK berdasarkan penanda RAPD.

Penelitian ini bertujuan untuk mempelajari keragaman pola pita DNA dan keseragaman populasi kelapa Genjah Salak (GSK) berdasarkan penanda RAPD.

Dengan diketahui tingkat keseragaman genetik kelapa GSK berdasarkan penanda RAPD, maka dapat dilakukan seleksi pohon induk dengan RAPD sebagai penanda.

\section{METODE PENELITIAN}

\section{Waktu dan Tempat}

Penelitian ini dilaksanakan selama 3 bulan yaitu sejak bulan Juli-September 2005. Materi penelitian yakni kelapa GSK diambil dari koleksi plasma nutfah di Kebun Percobaan Kima Atas, BALITKA Mapanget. Selanjutnya sampel daun kelapa untuk analisis DNAnya dilakukan di Laboratorium Fisiologi Tanaman, Fakultas Pertanian Unsrat Manado. 


\section{Bahan dan Alat}

Bahan yang digunakan dalam penelitian ini adalah daun muda (janur) dari 25 pohon kelapa Genjah Salak (GSK) yang dipilih berdasarkan rata-rata jumlah bunga betina $\geq 40$ (Sual 2005). Kelapa GSK yang diteliti ini adalah populasi yang dikoleksi oleh BALITKA Mapanget dari Desa Pematang Panjang, Kalimantan Selatan. Kelapa ini ditanam pada tahun 1991 dalam bentuk segitiga dengan jarak tanam $9 \times 9$ meter.

Alat-alat yang digunakan dalam penelitian ini adalah UVNisible Spectrophotometer Ultrospec 3300pro, Thermocycler Gene Amp PCR System 2700 Apped Biosystems, Elektroferesis gel, UV transluminator, dan photoman.

\section{Metode Penelitian}

Penelitan ini dilakukan di lapangan dan di laboratorium. Penelitian di lapangan dilakukan pengambilan sampel daun kelapa kemudian analisis DNA di laboratorium.

Penentuan pohon contoh yaitu yang memiliki kriteria tanaman sehat, jumlah buah banyak dan jumlah bunga betina banyak (rata-rata $\geq 40$ ). Selanjutnya pengambilan sampel daun yaitu daun muda (janur) dengan cara dipanjat kemudian helaian daun yang telah diambil dimasukkan kedalam plastik dan disimpan di dalam coolbox untuk dianalisis di laboratorium.

\section{Isolasi DNA.}

Isolasi DNA total di-lakukan berdasarkan Rohde, Kullaya, Rodrigues and Ritter (1995) yang telah dimodifikasi. Daun muda (janur) tanaman kelapa seberat $1 \mathrm{~g}$ digerus bersama $10 \mathrm{ml}$ bufer lisis (100 mM Tris $\mathrm{HCl} \mathrm{pH} 8,1,4 \mathrm{M} \mathrm{NaCl}$, $20 \mathrm{Mm}$ EDTA, $20 \%$ CTAB, 0,2 \% $\beta$ - merkaptoetanol ditambahkan pada saat akan digunakan) lalu dimasukkan kedalam tabung sentrifus $15 \mathrm{ml}$. Setelah diinkubasi selama 60 menit pada $60^{\circ} \mathrm{C}$, larutan yang mengandung DNA dikoleksi dengan disentrifus pada kecepatan 10.000 rpm selama 15 menit lalu diekstraksi dengan klorofom sebanyak 2 kali. Selanjutnya DNA dipresipitasi dengan menambahkan 0,8 volume isopropanol lalu diendapkan dengan disentrifus pada kecepatan 10000 rpm selama 15 menit. Kemudian DNA dibilas dengan alkohol $70 \%$ lalu dikeringkan. Terakhir DNA dilarutkan dengan milli-Q water steril sebanyak $200 \mu$ l.

Konsentrasi DNA di ukur menggunakan UVI Visible Spectrophotometer Ultrospec 3300pro yang ditentukan berdasarkan nilai absorbansi $A_{260}$, nilai $A_{260}=$ setara dengan $50 \mu \mathrm{g}$ DNA/ml. Sedangkan kemurniannya ditentukan berdasarkan $A_{260} / A_{280}$. DNA yang murni mempunyai perbandingan $\quad A_{260} / A_{280}=1,8-2,0$ (Sambrook, Fritch, and Maniatis 1989).

\section{Amplifikasi PCR.}

Amplifikasi PCR DNA dilakukan menggunakan mesin Thermocyler Gene Amp PCR System 2700 Applied Biosystems dengan volume reaksi PCR sebanyak $25 \mu$, yang me-ngandung 10 $\mathrm{mM}$ Tris- $\mathrm{HCl}, 50 \mathrm{mM} \mathrm{KCl}, 1,5 \mathrm{mM} \mathrm{MgCl}$, $200 \mathrm{M}$ dNTP, $5 \mu \mathrm{l}$ primer, dan $5 \mu \mathrm{l}$ template DNA . Kondisi amplifi-kasi PCR yang digunakan: (1). Pra-PCR $94^{\circ} \mathrm{C} / 5$ menit, (2). Denaturasi $94^{\circ} \mathrm{C} / 1$ me-nit, (3). Pelekatan primer $37^{\circ} \mathrm{C} / 1$ menit, (4). Pemanjangan DNA $72^{\circ} \mathrm{C} / 2$ menit).

Primer yang digunakan sebanyak 35 primer Operon Kit $A$ dan kit $B$, yaitu: 1). OPA 03, 2) OPA 04 3) OPA 05, 4). OPA 07, 5). OPA 08, 6). OPA 09, 7). OPA 10, 8). OPA 11, 9). OPA 13, 10). OPA 14, 11). OPA 15, 12). OPA 16, 13). 
OPA 17, 14). OPA 18, 15). OPA 19, 16). OPA 20, 17). OPB 01, 18). OPB 02, 19). OPB 03, 20). OPB 04, 21). OPB 05, 22). OPB 06, 23). OPB 07, 24). OPB 08, 25). OPB 09, 26). OPB 10, 27). OPB 11, 28). OPB 13, 29). OPB 14, 30). OPB 15, 31). OPB 16, 32). OPB 17, 33). OPB 18, 34). OPB 19, 35). OPB 20)

\section{Elektroforesis DNA.}

DNA hasil amplifikasi PCR setelah ditambah de-ngan $5 \mu$ bromofenol blue dielektrofore-sis pada $70 \mathrm{~V}$ selama 2 jam dalam $1,5 \%$ gel agarosa lalu diwarnai dengan etidium bromide selama 15 menit. Pita DNA hasil amplifikasi diamati pada UV translumina-tor dilanjutkan dengan pemotretan meng-gunakan film polaroid 667.

\section{Analisis Data}

Pita DNA yang diamati di atas UV transluminator diterjemahkan dalam data biner dengan ketentuan nilai 0 (nol) untuk yang tidak ada pitanya dan 1 (satu) untuk yang ada pitanya. Data biner yang diperoleh seluruhnya kemudian digunakan untuk menyusun matriks kesamaan (jarak genetik) antar individu kelapa, dengan menggunakan koefisien Jaccard dengan persamaan (Cox and Cox 1994):

$$
\begin{aligned}
& S_{r s}=\frac{A}{A+B+C} \\
& \mathrm{~S}_{\mathrm{rs}}=\begin{array}{l}
\text { Nilai kesamaan genetik antar } \\
\text { individu tanaman } \mathrm{r} \text { dan individu } \\
\text { tanaman } \mathrm{s}
\end{array} \\
& \mathrm{A}=\begin{array}{l}
\text { Jumlah pita DNA yang terdapat } \\
\text { baik pada tanaman } \mathrm{r} \text { maupun in- } \\
\text { dividu tanaman } \mathrm{s}
\end{array} \\
& \mathrm{B}=\begin{array}{l}
\text { Jumlah DNA yang hanya terda- } \\
\text { pat pada individu tanaman } \mathrm{s}
\end{array} \\
& \mathrm{C}=\begin{array}{l}
\text { Jumlah pita DNA yang hanya } \\
\text { terdapat pada individu tanaman }
\end{array}
\end{aligned}
$$

Pengelompokkan individu pohon kelapa berdasarkan kesamaan genetik dilakukan menggunakan metode UPGMA (unwighted pair group method arithmetic) melalui program NTSYS (numerical taxonomy and multivariete system) versi 1.700. Pengelompokan ini menghasilkan dendogram yang memperlihatkan hubungan kemiripan atau keragaman genetik antar individu pohon kelapa GSK yang diamati.

\section{HASIL DAN PEMBAHASAN}

\section{Profil Penanda RAPD Kelapa Genjah Salak (GSK)}

Pengamatan profil pita DNA hasil amplifikasi PCR DNA genomik 25 individu pohon Kelapa Genjah Salak (GSK), yang diamplifikasi menggunakan 35 primer Operon Kit A dan kit, 2 primer diantaranya, yaitu OPA 09 dang OPB 06 menghasilkan pita DNA monomorfik dan 3 primer diantaranya menghasilkan pita DNA yang polimorfik, yaitu OPA 13, OPB 05 , dan OPB 10 (Gambar 1) .

Banyaknya pita DNA hasil amplifikasi ketiga perimer tersebut di atas berkisar antara 3 sampai 8 pita DNA (Tabel 1). Pita-pita DNA yang diamplifikasi tersebut berukuran antara 643-5.090 pb. Susunan basa nukleotoda masing-masing primer yang berhasil mengamplifikasi DNA genomic 25 individu pohon kelapa GSK disajikan pada Tabel 2. Sedangkan 30 primer lainnya tidak berhasil mengamplifikasi DNA genomic 25 individu pohon kelapa GSK tersebut diduga mengalami kerusakan karena selama disimpan dalam refrigerator sebelum pemakaian, listrik yang digunakan tidak stabil menyebabkan suhu penyimpanan tidak konsisten.. 


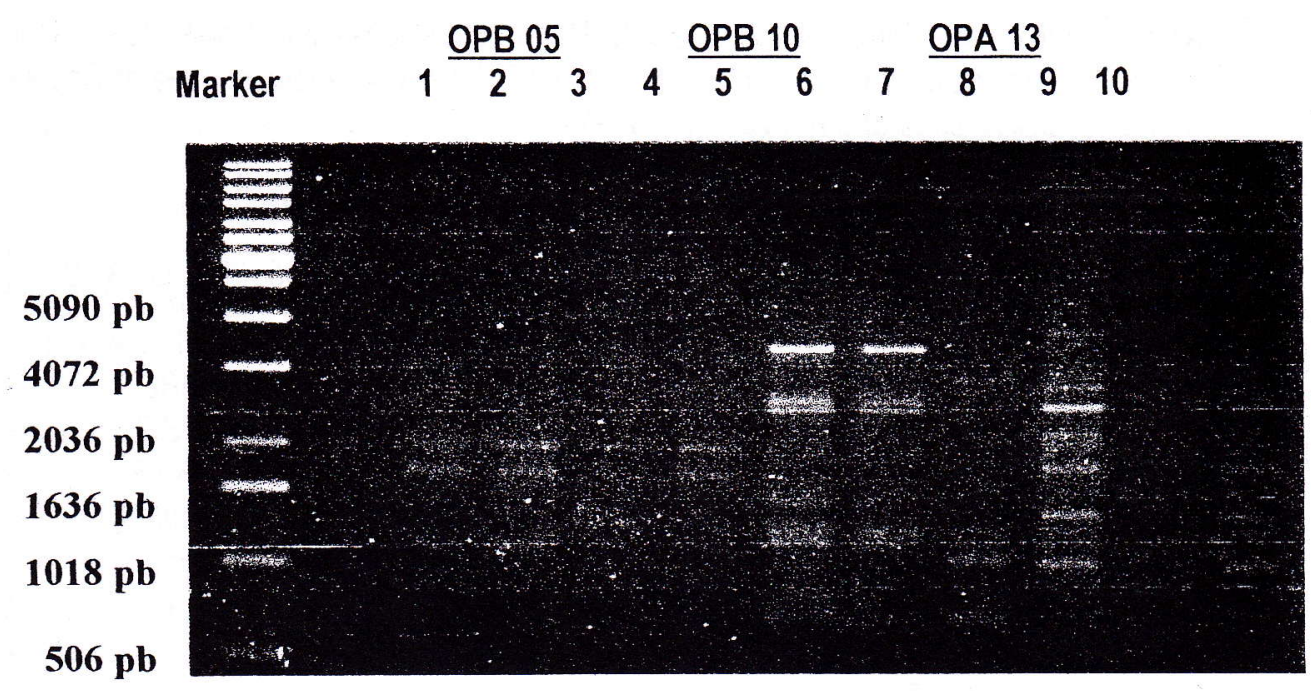

Gambar 1. Profil pola pita DNA kelapa GSK hasil amplifikasi PCR. Angka 1-4 (GSK23, GSK15, GSK51, GSK77) menggunakan primer OPB05, angka 5-7 (GSK23, GSK65, GSK69) menggunakan primer OPB10, angka 8-10(GSK23, GSK47,GSK66) menggunakan primer OPA13. Marker = DNA $1 \mathrm{~kb}$ ladder, $\mathrm{pb}=$ pasang basa.

Total pita DNA yang diamplifikasi sebanyak 19 pita DNA dan 9 (47\%) pita DNA diantaranya adalah polimorfik. Pita DNA yang polimorfik menunjukkan keragaman genetik tanaman yang Dianalisis.

Keragaman Pola Pita DNA dan Keseragaman Populasi Kelapa Genjah Salak (GSK)

Berdasarkan analisis matriks kesamaan diantara 25 individu pohon kelapa GSK diperoleh rata-rata keragaman genetik sebesar $12 \%$ atau kesamaan genetik sebesar $88 \%$. Hasil ini jika dibandingkan dengan penelitian Aror (2004) de- ngan teknik RAPD menggunakan 5 primer (OPA 04, OPA 09, OPA 15, OPA 18, OPB 07) pada analisis 30 individu pohon kelapa GSK yang berasal dari PT. Pagelaran Jawa Tengah menghasilkan 52 pita dan $24(46,15 \%)$ diantaranya adalah pita polimorfik dengan rata-rata keragaman genetik sebesar $10 \%$ dimana keragaman terkecil sebesar $2 \%$ dan keragaman terbesar $23,4 \%$. Pada keragaman genetik $10 \%$ populasi kelapa GSK terbagi dalam 12 kelompok. Rata-rata kesamaan genetik yang dihasilkan tidak berbeda jauh (2\%) karena kelapa GSK termasuk tipe menyerbuk sendiri. 
Tabel 1. Banyaknya Pita DNA 25 Individu Pohon Kelapa Genjah Salak (GSK) Hasil Amplifikasi 3 Primer (The Total of DNA Tape of 25 Individu Tree of Coconut GSK Result of 3 Primer Amplification)

\begin{tabular}{|c|c|c|c|}
\hline \multirow{2}{*}{ Nomor Pohon Individu Kelapa GSK } & \multicolumn{3}{|c|}{ PRIMER } \\
\cline { 2 - 4 } & OPA 13 & OPB 05 & OPB 10 \\
\hline 7 & 5 & 5 & 5 \\
8 & 5 & 5 & 5 \\
10 & 5 & 5 & 5 \\
12 & 5 & 5 & 5 \\
14 & 5 & 5 & 5 \\
20 & 5 & 5 & 5 \\
23 & 6 & 3 & 5 \\
24 & 6 & 3 & 5 \\
28 & 5 & 5 & 5 \\
32 & 5 & 5 & 5 \\
37 & 6 & 5 & 5 \\
41 & 5 & 5 & 5 \\
47 & 5 & 5 & 5 \\
49 & 5 & 5 & 5 \\
51 & 6 & 7 & 5 \\
55 & 6 & 8 & 5 \\
56 & 6 & 5 & 5 \\
64 & 5 & 5 & 5 \\
65 & 5 & 5 & 5 \\
66 & 5 & 5 & 5 \\
69 & 6 & 3 & 3 \\
71 & 6 & 3 & 5 \\
77 & 5 & 3 & 5 \\
91 & 5 & 3 & 3 \\
92 & 5 & 3 & 3 \\
\hline
\end{tabular}

Tabel 2. Jenis Primer, Susunan Basa Nukleotida, Jumlah Pita yang Dihasilkan, Jumlah Pita Polimorfik (The Primer Kind, Composition of Nucleotide Alkali, Total Produce Tape, Total Polimorfic Tape)

\begin{tabular}{|c|c|c|c|c|}
\hline No. & Primer & Susunan Basa Nukleotida & Jumlah Pita & $\begin{array}{c}\text { Jumlah Pita } \\
\text { Polimorfik }\end{array}$ \\
\hline 1 & OPA 13 & C A G C A C C C A C & 6 & 1 \\
2 & OPB 05 & T G C G C C C T T C & 8 & 5 \\
3 & OPB 10 & C T G C T G G G A C & 5 & 3 \\
\hline \multicolumn{2}{|c|}{ Total } & 19 & 9 \\
\hline
\end{tabular}


Analisis pengelompokkan keragaman genetik individu dalam populasi besar dapat dilihat pada Gambar 2 selanjutnya berdasarkan analisis pengelompokkan tersebut, pada keragaman genetik $12 \%$ terbentuk 5 kelompok dimana terdiri dari satu kelompok besar yaitu individu pohon kelapa GSK7, GSK8, GSK10, GSK12, GSK14, GSK20, GSK23, GSK24, GSK28, GSK32, GSK37, GSK41, GSK47, GSK49, GSK51, dan GSK55. Kelompok kedua terdiri dari individu pohon kelapa GSK 56 dan GSK 64. Kelompok ketiga terdiri dari individu pohon kelapa GSK 65 dan GSK 66, GSK 69 , dan GSK 71. Kelompok keempat terdiri dari individu pohon kelapa GSK77. Sedangkan kelompok kelima terdiri individu pohon kelapa GSK 91 dan GSK 92. Keragaman tertinggi terdapat diantara individu pohon kelapa GSK 77, GSK 91 dan GSK 92 yaitu sebesar $27 \%$.

Pada kesamaan genetik $100 \%$ terdapat 4 kelompok. Kelompok satu (terbesar) terdiri dari 14 individu pohon kelapa yaitu GSK 7, GSK 8, GSK10, GSK12, GSK14, GSK 20, GSK 23, GSK 24, GSK 28, GSK 32, GSK 37, GSK 41, GSK 47, GSK 49. Kelompok kedua terdiri dari individu pohon kelapa GSK51, dan GSK 55. Kelompok ketiga terdiri dari individu pohon kelapa GSK 65, GSK 66,dan GSK 69. Kelompok keempat terdiri dari individu pohon kelapa GSK 91 dan GSK 92.

Pengelompokkan individu-individu ini dapat disebabkan oleh sistem penyerbukannnya. Walaupun tipe penyerbukan kelapa GSK termasuk dalam tipe menyerbuk sendiri tetapi tidak menutup kemungkinan untuk menyerbuk silang meskipun kecil. Selain itu juga faktor lain yang memungkinkan terjadinya pengelompokkan tersebut yaitu kelapa GSK yang dikoleksi BALITKA tidak berasal da- ri satu tetua. Hal ini dapat dilihat pada analisis pengelompokkan dimana terdapat 14 pohon yang memiliki kesamaan genetik $100 \%$ yang dapat disebabkan oleh sistem penyerbukannya yaitu menyerbuk sendiri dan dapat juga disebabkan berasal dari satu tetua. Demikian halnya dengan kelompok yang terdiri dari 2 dan 3 individu pohon kelapa GSK. Sedangkan kelompok-kelompok yang terdiri dari satu individu pohon kelapa GSK disebabkan oleh penyerbukan silang atau berasal dari tetua yang berbeda. Proporsi penyerbukan silang beberapa kelapa Genjah koleksi BALITKA Mapanget berkisar 1,2-33,9 \% (Tampake 2003).

\section{Pemanfaatan Kelapa Genjah Salak (GSK) Berdasarkan Informasi Studi RAPD}

Berdasarkan hasil analisis RAPD ini terdapat keragaman genetik antar individu dalam populasi kelapa GSK. Sehingga untuk kegiatan pemuliaan kelapa dalam memilih individu tanaman untuk dijadikan tetua dalam persilangan diperlukan seleksi individu atau kelompok berdasarkan tingkat kesamaan genetik. Untuk individu-individu yang akan dijadikan tetua dalam persilangan yang seragam yaitu ke-14 individu pohon kelapa yang memiliki kesamaan genetik $100 \%$ yaitu GSK 7, GSK 8, GSK10, GSK12, GSK14, GSK20, GSK23, GSK24, GSK28, GSK32, GSK37, GSK41, GSK47, GSK49. Selain dijadikan tetua untuk persilangan, keempatbelas individu tersebut dapat menghasilkan benih yang seragam dalam jumlah yang banyak. Disamping itu juga dapat dimanfaatkan untuk perbanyakan tanaman lewat kultur jaringan guna memperoleh tanaman yang homogen. 
Kesamaan Genetik

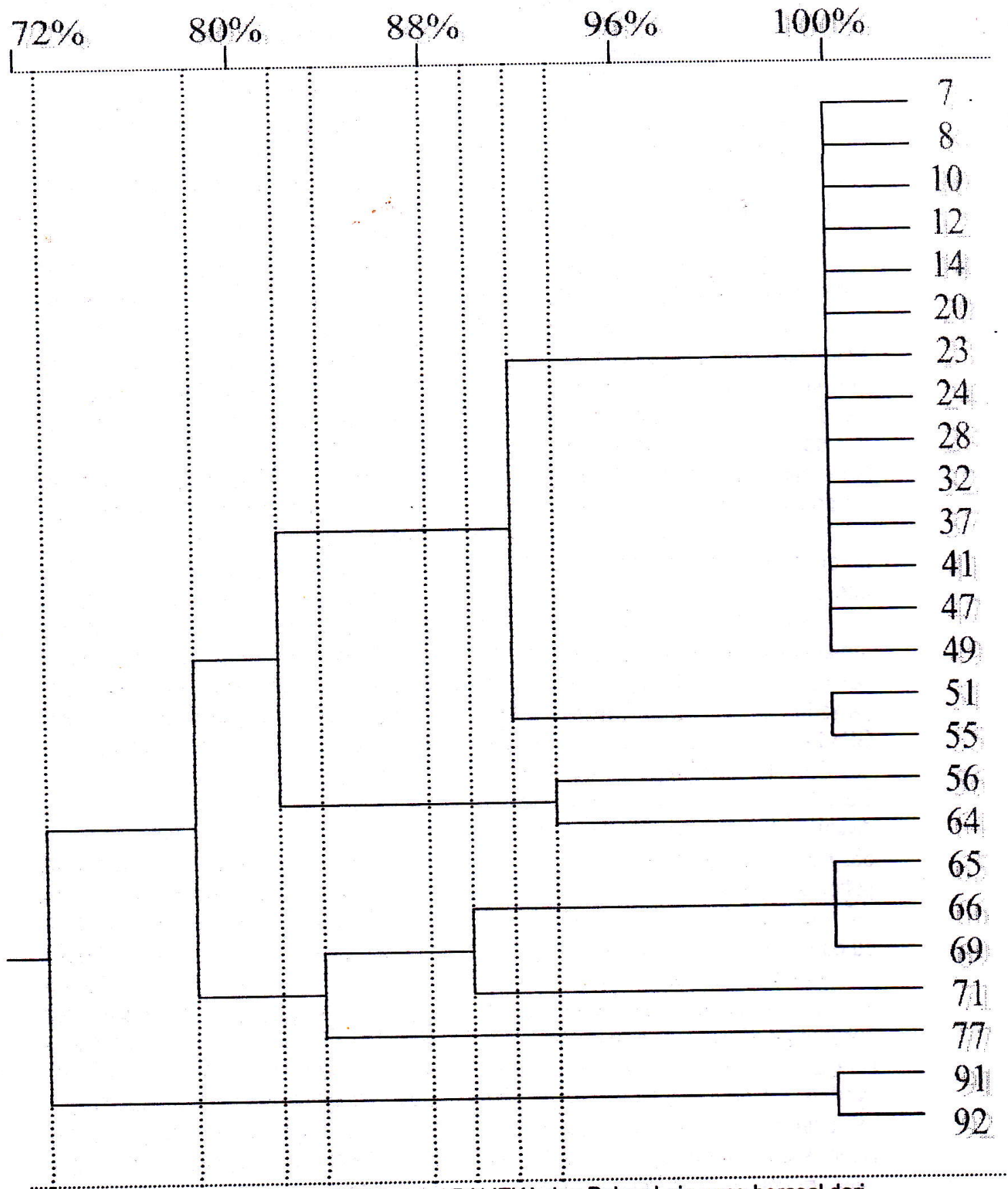

Gambar 2. Dendogram Kelapa GSK koleksi BALITKA dan Palma Lain yang berasal dari Pematang Panjang, Kalimantan Selatan 
Untuk individu yang memiliki keragaman yang luas, dalam kegiatan pemuliaan dapat digunakan untuk mendapatkan varietas yang lebih unggul dari yang sudah ada. Karena semakin jauh jarak genetik dari tetua yang disilangkan maka peluang untuk mendapatkan varietas unggul semakin besar (Enny, Tampake dan Novarianto 1993). Perakitan kelapa unggul akan berhasil baik jika tersedia plasma nutfah yang beragam.

Sesuai dengan tujuan pemuliaan kelapa yang diarahkan pada perakitan kelapa unggul yang berproduksi buah dan kopra serta minyak yang tinggi, maka metode yang diprioritaskan adalah seleksi dan hibridisasi kelapa dengan tujuan menghasilkan keanekaragaman jenis kelapa unggul (Novarianto 2005).

\section{KESIMPULAN DAN SARAN}

\section{Kesimpulan}

Hasil amplifikasi DNA genom dari 25 individu pohon kelapa Genjah Salak (GSK) menggunakan 3 primer yaitu OPA 13, OPB 05, dan OPB 10 menghasilkan jumlah pita antara 3 sampai 8 dengan resolusi yang berbeda-beda dan berukuran antara 643 - 5090 pasang basa. Dengan jumlah pita polimorfik yang dihasilkan 9 (47 \%) pita dari 19 pita hasil amplifikasi.

Kesamaan genetik pada populasi kelapa Genjah Salak (GSK) berdasarkan penanda RAPD rata-rata sebesar $88 \%$ atau memiliki keragaman genetik $12 \%$. Dimana pada kesamaan ini populasi kelapa GSK dikelompokkan atas 5 kelompok.

Pada kesamaan genetik $100 \%$ terdapat 4 kelompok. Kelompok satu (terbesar) terdiri dari 14 individu pohon kelapa yaitu GSK 7, GSK 8, GSK10, GSK12, GSK14, GSK 20, GSK 23, GSK 24, GSK
28, GSK 32, GSK 37, GSK 41, GSK 47 , GSK 49. Keempatbelas individu ini dapat digunakan sebagai tetua dalam persilangan untuk program pemuliaan kelapa untuk memperoleh hasil persilangan yang seragam. Sedangkan individu yang memiliki keragaman yang luas dalam kegiatan pemuliaan dapat digunakan untuk meridapatkan varietas yang lebih unggul.

\section{Saran}

Berdasarkan hasil penelitian ini, untuk koleksi plasma nutfah dapat menggunakan semua tanaman untuk mendapatkan keanekaragaman genetik. Sedangkan untuk kegiatan pemuliaan lebih lanjut untuk mendapatkan sumber benih yang homogen sebaiknya menggunakan individu pohon kelapa yang memiliki kesamaan genetik $100 \%$.

\section{UCAPAN TERIMA KASIH}

Penelitian ini dibiayai oleh Proyek Penelitian Hibah Bersaing Perguruan Tinggi, DIKTI Tahun Anggaran 2005 atas nama Dr. Ir. Semuel D. Runtunuwu.

\section{DAFTAR PUSTAKA}

Akuba, R. H. 1998. Dampak Kekeringan dan Kebakaran Terhadap Kelapa dan Upaya Penanggulangannya. Prosiding Konfrensi Nasional Kelapa IV. Bandar Lampung. 21-23 April Hal. 233244.

Aror, I. E. P. 2004. Keragaman Genetik Kelapa Genjah Salak (GSK) Berdasarkan Penanda RAPD. Skripsi. Fakultas Pertanian. UNSRAT. Manado. 
Aswidinnor, H. 1991. Rekayasa Genetik. P 96-186. In Said Garan dan Nurhayati Ansory (editor) Bioteknologi Pertanian II, Pusat Antar Universitas Bioteknologi IPB. Bogor.

Billote, N. 1996. Coconut Genetic Improvement Programme an Balitka. Final Report 1989/1995 Bogor: AARD-CIRAD-CP COOPERATION.

Cox, T. F and M. A. A. Cox. 1994. Multidimensional Scaling Chapman and Hall. London.

Djatmiko, B. 1991. Karakterisasi Daging Buah Beberapa Kultivar Kelapa. Jurnal Penelitian Kelapa. 5(1): 12-16.

Enny, R., H. Tampake dan H. Novarianto. 1993. Jarak Genetik Beberapa Jenis Kelapa Hibrida Genjah x Dalam berdasarkan Sifat Kuantitatif dan Pola Pita Isozim. Jurnal Penelitian Kelapa 6(1):62-67

Novarianto, H. 2005. Plasma Nutfah dan Pemuliaan Kelapa. BALITKA. Manado. (akan diterbitkan).

Rohde, W. A. Kullaya, J. Rodrigues and E. Ritter. 1995. Genome Analysis of Cocos nucifera L. by PCR Amplification of Spacer Sequences Separating a
Subset of Copia-like EcoRI Repetitive Elements. J. Genet. Breed. 49:179-186.

Runtunuwu, S.D., M. S. Sinaga, A. Hartana, 1999. Seleksi Ketahanan Tanaman Kelapa Terhadap Penyakit Gugur Buah (Phytophtora palmivora BUTLER). Buletin Hama dan Penyakit Tumbuhan. Jurusan HPT IPB. Bogor.

Sambrook, J., E. F. Fritch, and T. Maniatis. 1989. Molecular Clonning. A Laboratory Manual. Cold Spring Harbor Lab. CHS. New York.

Sual, H.M. 2005. Keragaman Bunga Betina dalam Populasi Kelapa Genjah Salak di KP. BALITKA Kima Atas. Makalah Hasil Penelitian. Fakultas Pertanian Unsrat. Manado.

Tampake, H. 2003. Monograf Plasma Nutfah Kelapa Indonesia. Badan Litbang Pertanian. BALITKA. Manado. .

Tenda, E. T. 2004. Perakitan Kelapa Hibrida Intervarietas dan Pengembangannya di Indonesia. Perspektif Review Penelitian Tanaman Industri 3(2): 3545. 